\title{
Development of Information System Management Customer Satisfaction Using the Simple Additive Weighting Method and Website-Based Google Maps API at ISP XYZ
}

\author{
Ahmad Habib ${ }^{1}$, Putra Aditya Nova, Ardy Januantoro \\ Department of Informatics Engineering \\ Universitas 17 Agustus 1945, Surabaya, Indonesia \\ 1habib@untag-sby.ac.id
}

\begin{abstract}
Internet Service Provider XYZ is a service company that provides a variety of Internet service package products, cloud data, communication networks, and complete installations, as well as various local and international TV channel service packages interactively using fiber optic technology. However, over time, problems arose, where many customers complained about the troubleshooter service management provided by the ISP, for example, related to reports of disturbances from customers, the length of time in handling disturbances, the lack of clarity of officers who handled disturbances and so on which led to a decrease in the level of customer satisfaction. To deal with these problems, researchers developed a customer satisfaction management information system by applying the Simple Additive Weighting method supported by a websitebased google maps API to solve the problems being faced by ISP XYZ. The results of the system development are expected to facilitate and speed up the handling of problems that are being experienced by customers and with the application of the SAW method can easily find out the level of customer satisfaction at the XYZ ISP.
\end{abstract}

Keywords- Information System Management, Customer Satisfaction, SAW, google maps API.

\section{INTRODUCTION}

With rapid progress and increasing human needs, especially in the fields of technology, information, and communication, consumers are encouraged to increase the intensity of their daily use of technology. It has become an indispensable part of it and has become a necessity of life. Internet is a mode of nonshareable data today. It can be seen from the number of internet cafes (alerts) that provide internet connection for their customers. This does not apply to individuals but applies to larger groups of people, such as businesses and offices. Deployment on a relative scale requires no small amount of capital. However, the need for the internet is always high. And this situation can be turned into a business by setting up an ISP. The use of the network on the internet can use various ways such as accessing a connection using a cable and accessing a connection called wireless. Users are required to subscribe to an ISP to use an internet connection. The function of the ISP itself is as a liaison between the internet network on a personal computer with a global personal computer network and the 2 types of networks owned have their respective advantages. A network connection using cable has advantages such as data access using an internet connection that is very stable because it is not blocked by the weather, and this makes it easier for internet users if they want to send data with large sizes but as a result the time needed will be shorter.[1]

The advantages of a wireless network have the advantage that it can be used anywhere where you want it because the network using wireless is not connected by cable, and the costs incurred to use a wireless network are also cheaper when compared to using a cable, and to the user if you want to mobilize that requires using an internet 
connection is also very good because it does not require a special location. At this time, the use of internet connections is more dominated or favored by using wireless or wireless access. The main thing used by the community is not being able to stay in front of a computer connected by cables for too long because everyone has a busy life and requires mobilization. on a wireless internet connection it can be used on several devices that have a connection feature on wifi such as smartphones, laptops, notebooks, and so on, even some people today are using internet access on a 4-wheeled vehicle or private car even though the device features the equipment used in the vehicle is inadequate when compared to the number of devices in the room.[2]

ISPs have provided services for connecting internet connections and other services related to the internet. ISPs have a network domestically and also reach international coverage so that customers on an ISP can connect to the global internet network. In the transmission media, several devices are used wired or wireless, namely modems, radios, VSAT, and bandwidth.[3]

In a communication and data service, there is still a satisfaction with customers who use the service, as a result, this research is needed to help resolve disputes over how satisfied customers are to find out things that affect customer satisfaction. SAW (Simple Additive Weighting), which is expected by using this method can help to find out how satisfied customers are[4].

\section{METHOD}

Data collection is done using interviews and observations. Researchers interviewed parties directly involved in the use of information technology. Then the researcher made observations with the parties directly involved in the use of information technology, the involvement of information technology in each transaction, and the parties involved in the transaction.[5] A. Understanding Customer Satisfaction
This shows that customer satisfaction is the view of the customer. Customer satisfaction is believed to have several main benefits

B. Understanding Information Systems

Understanding information can be obtained based on a message system (information system). Messaging systems are a requirement, both business and tactical. Organizing by processing, storing information. It is an organized way to store, manage, monitor, and present messages so that the organization can achieve its goals.

C. Understanding SAW

Understanding the simple additive weighting method usually uses the weighted word addition method. The basic idea of a simple additive weighting method is to find the number of alternative weights for all attributes based on performance evaluation. A multithreaded decision-making system recommends weights. Simple additive weighting is a widely used decisionmaking technique for multiple attributes. Additive weighting requires matrix normalization and comparison using alternative estimates.

D. Understanding ISP

ISP is a company that specializes in Internet services, the company invests its resources in building Internet network infrastructure. ISPs have domestic and international networks so that Customers or consumers can connect to the global Internet based on the connection provided by the ISP.

E. Understanding Organization

An organization is a formal alliance based on people working together to act for a goal to be achieved. Organizations are mainly used as seminars or seminars where people meet in a reasonable, systematic, planned, organized, managed, and controlled way when dealing with (costs, materials, machines, methods, and locations) forum.), infrastructure, information, etc. 
F. Understanding API

An API or application programming interface is a set of software protocols for interaction with other software. The goal is to make it easier for programmers to reuse software. No need to waste time writing and building software infrastructure. Back to infrastructure.

G. Understanding Google Maps API

Google Maps API is a service for developing applications using Google Maps. To use it a key is required and then included in the implementation code, or an API token or key is a unique code generated to enable access. Built on the official GMaps page. Google Maps API has a user or a developer on a software to be used to view a map of a place to provide a location or directions with the fastest alternative to user, Google Maps can display an address or the intended location by showing the latitude and longitude accordingly. on the location of the intended point, and Google Maps shows and calculates the time in real-time based on the date route.

\section{RESULT AND DISCUSSION}

\section{A. Research Method}

The research method is a set of research methods or activities based on potential assessments, philosophical and ideological views, problems, and information. From the explanation above, it can be seen if a research methodology plays an important role in research conducted and developed. Understanding research methods will make it easier for researchers to choose the method/approach that will be used in their research.[6]

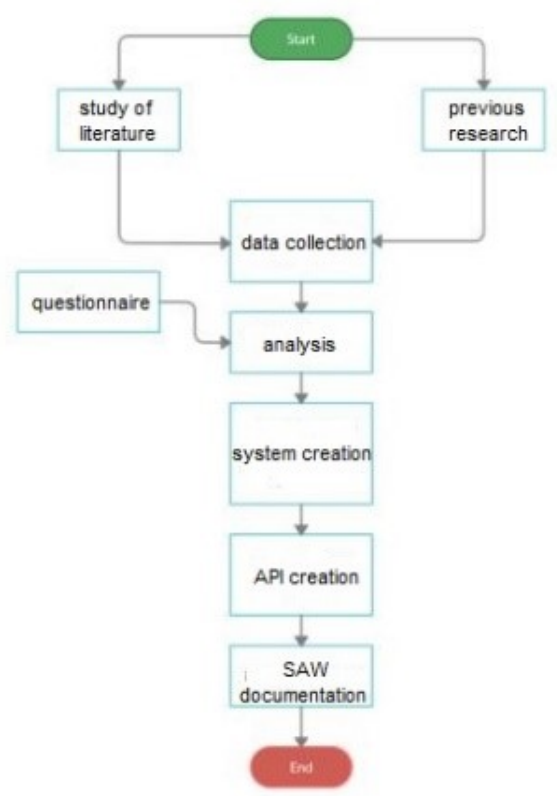

Figure 1. Research Methodology Flowchart

\section{B. System Planning}

A system and database design for the application of a SAW application according to the needs of the XYZ ISP Customer Satisfaction System.[7]

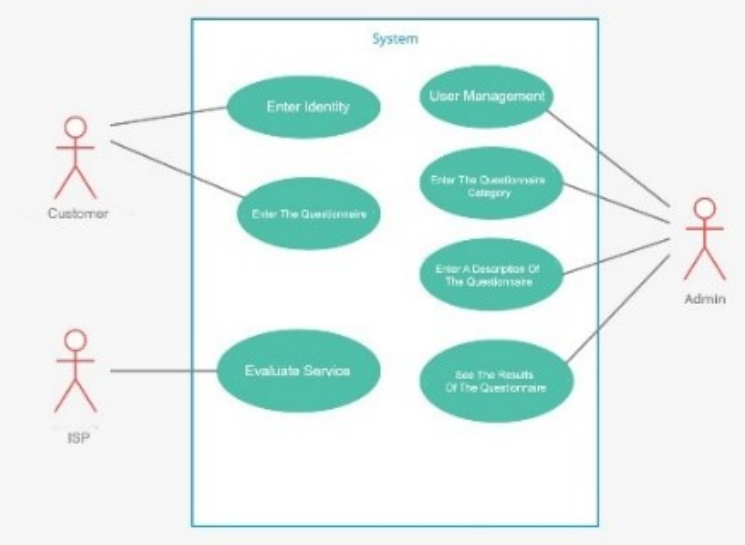

Figure 2. System Use Case

At the use case stage, the system explains the admin flow that acts as an adder, edits and deletes user data, questionnaire categories, questionnaire descriptions, and views the results of the completed questionnaires.[8]

Customers who act as inputs of customer identities, questionnaires, and comments or suggestions that have been made by the admin.[9]

ISP XYZ has the role of evaluating services from the results of the questionnaire. 


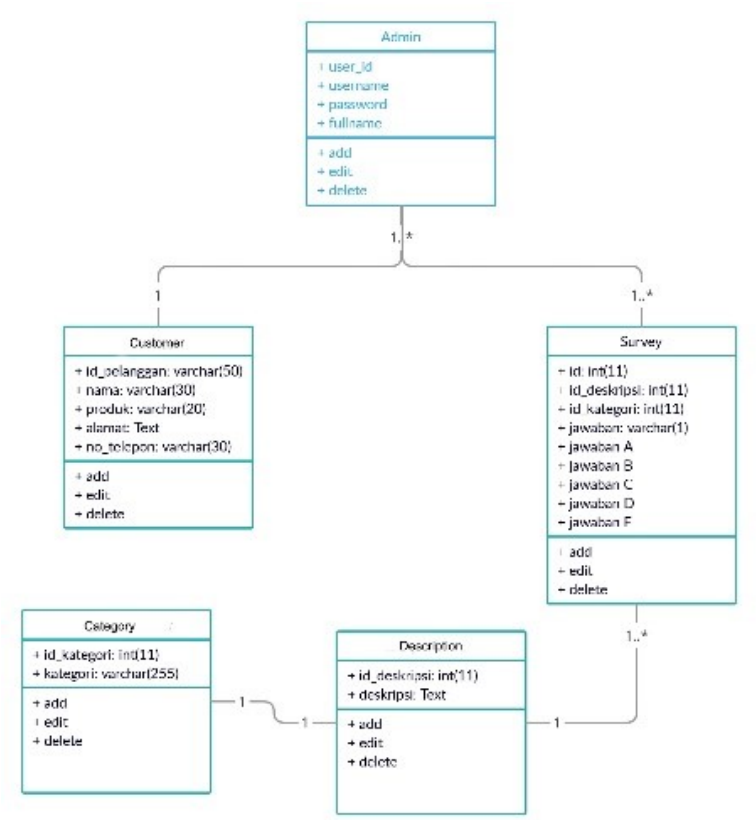

Figure 3. Class Diagram

The class diagram is a type of diagram that is often used in UML because it can clearly show the structure of a particular system by using an interaction model between classes, operations, and attributes, and objects. Class diagrams are described and described or represented based on classes, attributes and objects, and their interactions (such as inheritance, inclusion, association, etc.).[10]

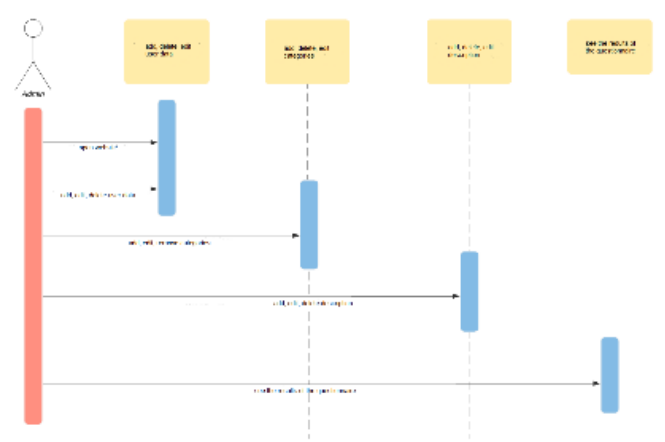

Figure 4. Admin Sequence

The admin sequence design explains the admin flow which has an added flow, edits if there is an input error, and deletes the user, questionnaire category, questionnaire description and sees the completed questionnaire results.[11]

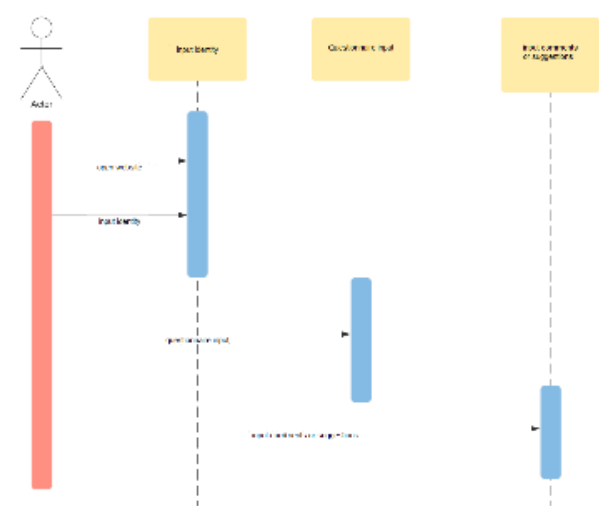

Figure 5. Customer Sequence

The customer sequence design explains the flow of the customer's questionnaire filling process which starts with filling in the customer's identity, filling out the questionnaire that has been provided, and filling in the comments or suggestions. The sequence design explains the flow of the customer which will rank the questionnaire results using SAW.[12]

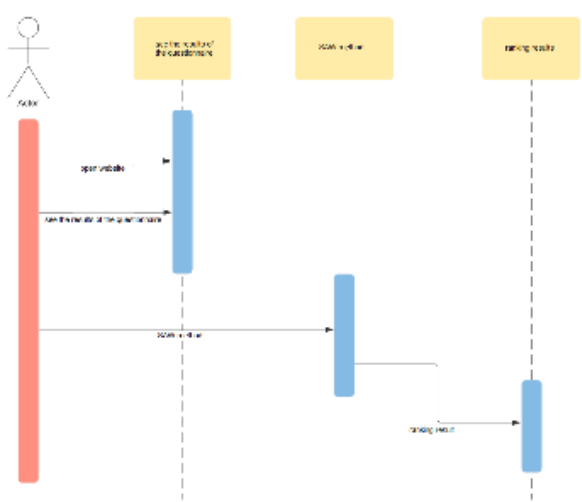

Figure 6. SAW Sequence

The SAW sequence design explains the ranking process flow obtained from the questionnaire data that has been filled out by the Customer The sequence design explains the ranking results obtained after the questionnaire results have been processed using SAW.[13] 


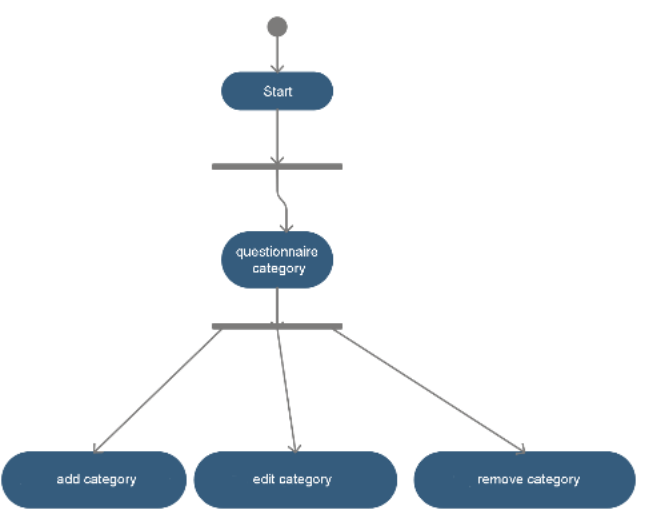

Figure 7. Activity Category

The questionnaire category activity diagram explains the activity diagram flow from the questionnaire category which can be added to categories, edit categories, and delete categories on the questionnaire.[14]

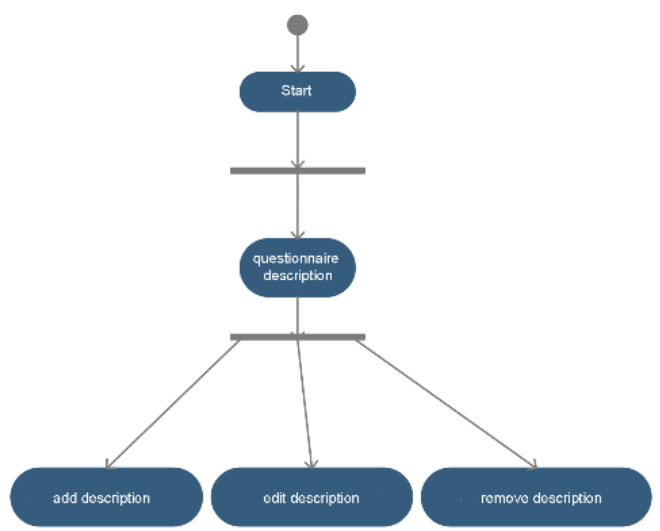

Figure 8. Activity Description

The activity diagram description of the questionnaire describes the flow of activity diagrams from the description of the questionnaire that can be added descriptions, edit descriptions, and delete descriptions on the questionnaire.

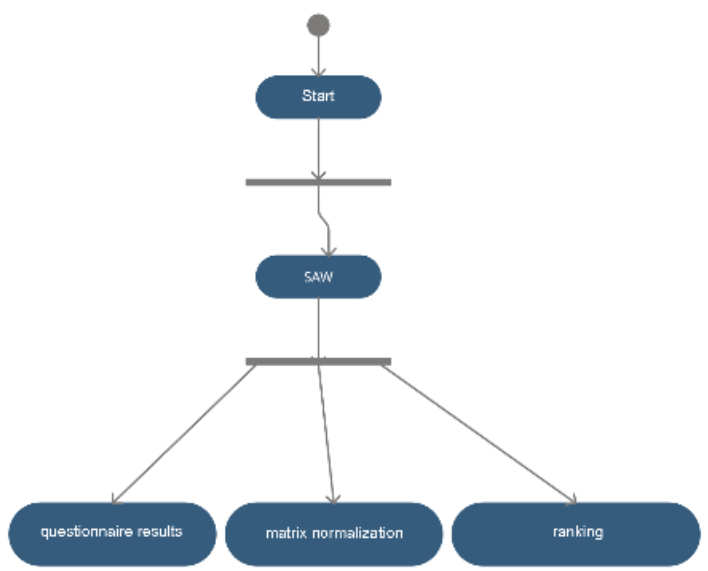

Figure 9. Activity SAW
The activity diagram SAW explains the flow of the activity diagram from SAW by collecting the results of the questionnaire that has been filled in by the customer then the matrix normalization process is carried out after that the ranking process is carried out so that the results of customer satisfaction are known.

\section{Mockup Design}

Mockup design will be done after doing the design.

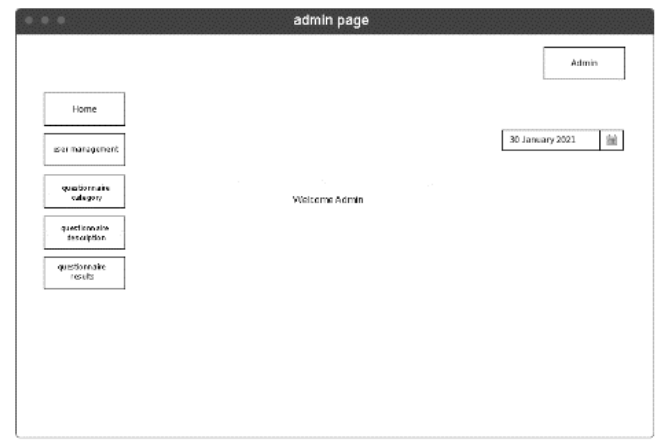

Figure 10. Admin Mockup

Figure 10 is a mockup display of the admin page where there are several menus, including home, user management, questionnaire category management, questionnaire description management, and questionnaire results.

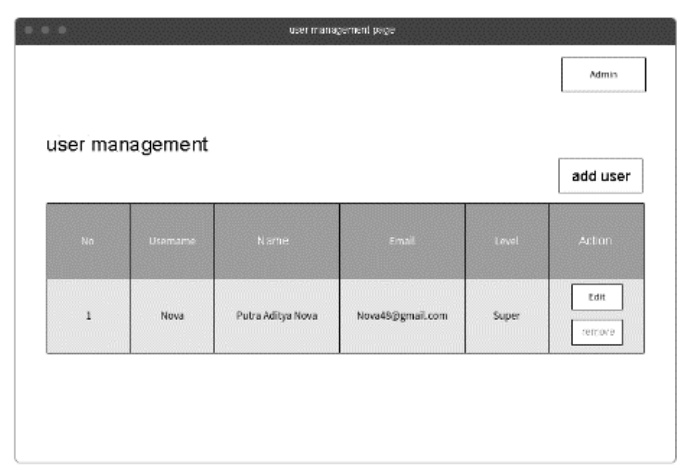

Figure 11. User Mockup

Figure 11 is a mockup display of the user management page where there is a user added feature, edit if there is an input error, and delete it if the user is no longer needed. 


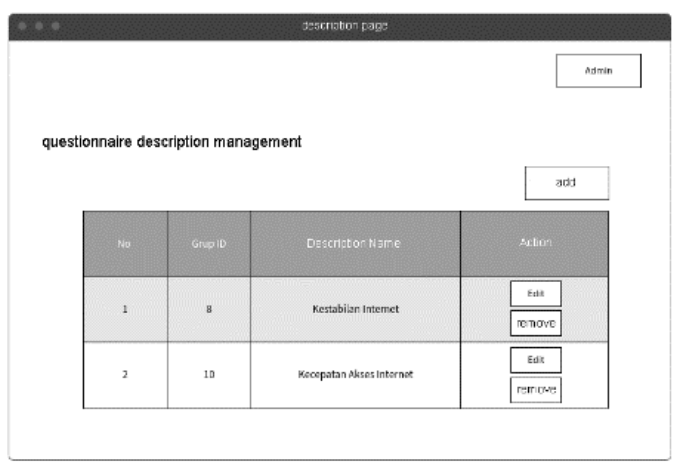

Figure 12. Description Mockup

Figure 12 is a mockup display of the questionnaire description management page where there is a feature to add a questionnaire description, edit it if you want to change the description, and delete it if the description is not needed.

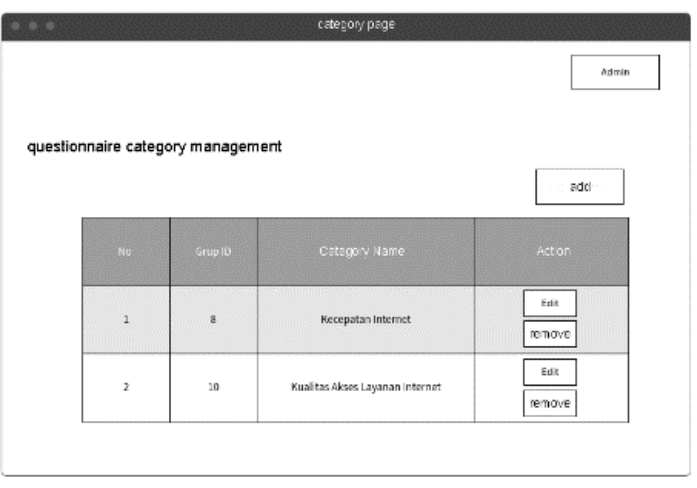

Figure 13. Category Mockup

Figure 13 is a mockup display of the questionnaire category management page where there is a category add the feature, edit the questionnaire category if you want to change the category, and delete it if the category is not needed.

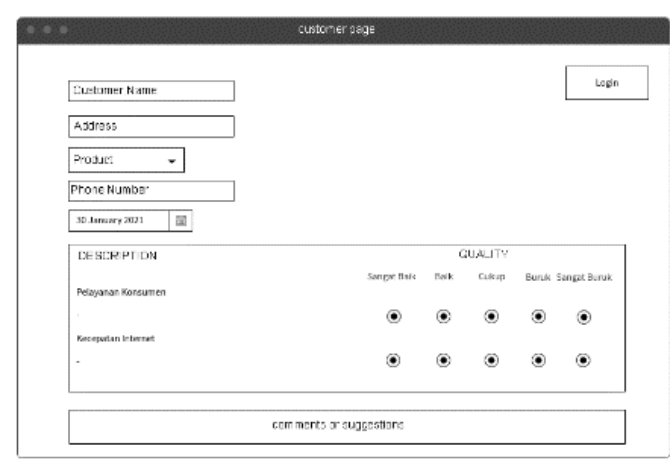

Figure 14. Customer Mockup
Figure 14 is a mockup display of the Customer page where there are several forms for the Customer's name, address, product, and telephone number, and the Customer can choose the answer to answer the questionnaire and add comments/suggestions.

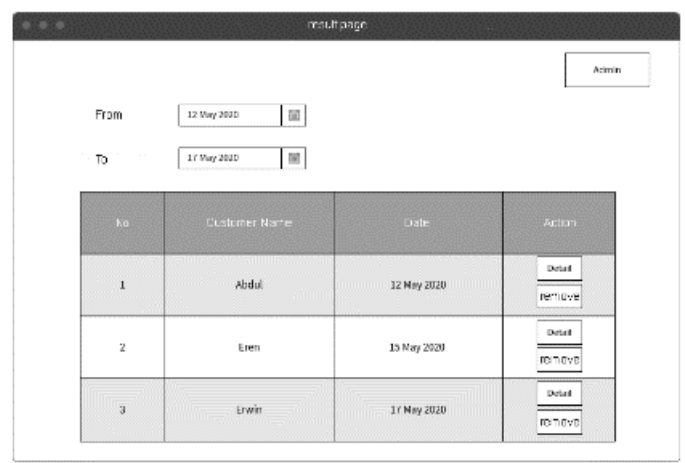

Figure 15. Result Mockup

Figure 15 is a mockup display of the results page where there is a date feature to view the results of the questionnaire from what date to what date, details to view the results of the questionnaire in detail, and delete to delete the results of the questionnaire.

\section{Result Display}

The stage of making this application is a process which is a stage where you will make the application from start to finish according to the existing mockup or design.

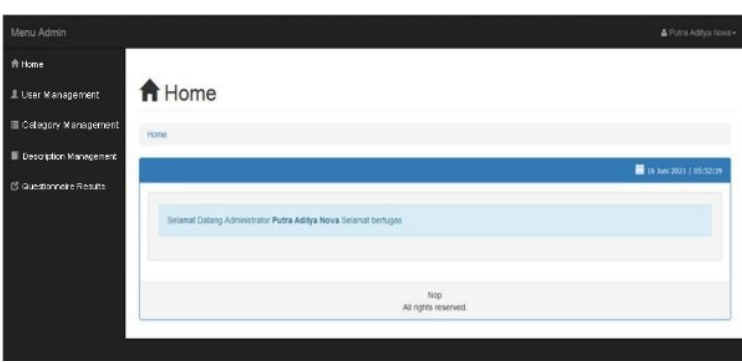

Figure 16. Admin Display

Figure 16 is a display of the admin page where there are several menus, including home, user management, questionnaire category management, questionnaire description management, and questionnaire results. 


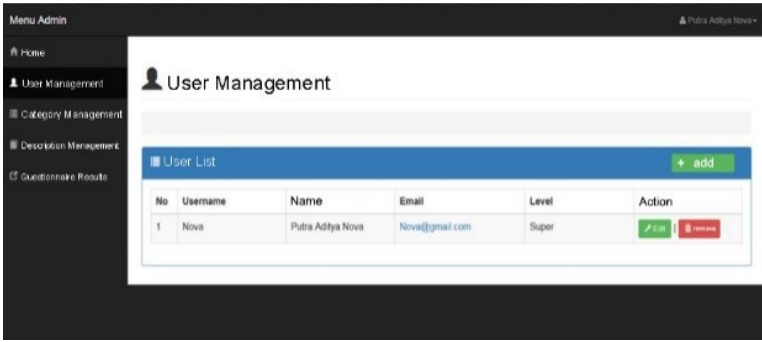

Figure 17. User Display

Figure 17 is a display of the user management page where there is a user added feature, edit if there is an input error, and delete it if the user is no longer needed.

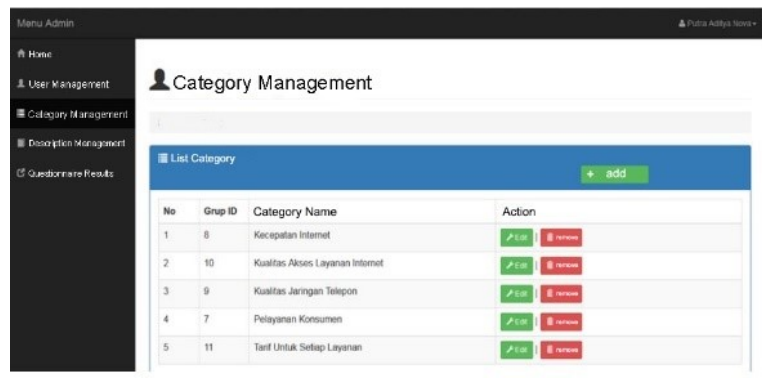

Figure 18. Category Display

Figure 18 is a questionnaire category page where there is a category add the feature, edit the questionnaire category if you want to change the category, and delete it if the category is not needed.

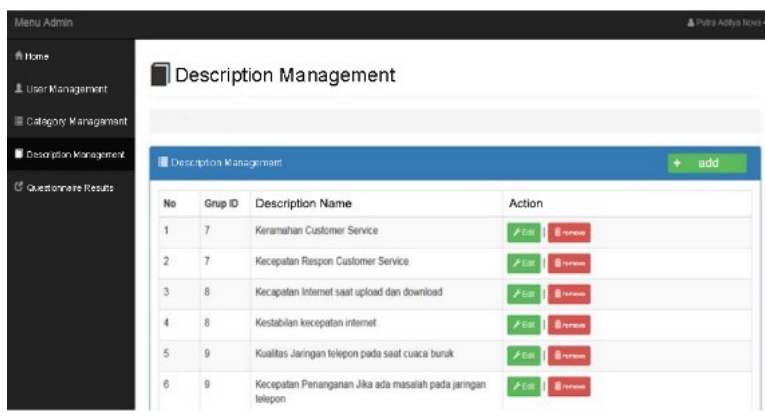

Figure 19. Description Display

Figure 19 is a questionnaire description page where there is a feature to add a questionnaire description, edit it if you want to change the description, and delete it if the description is not needed.

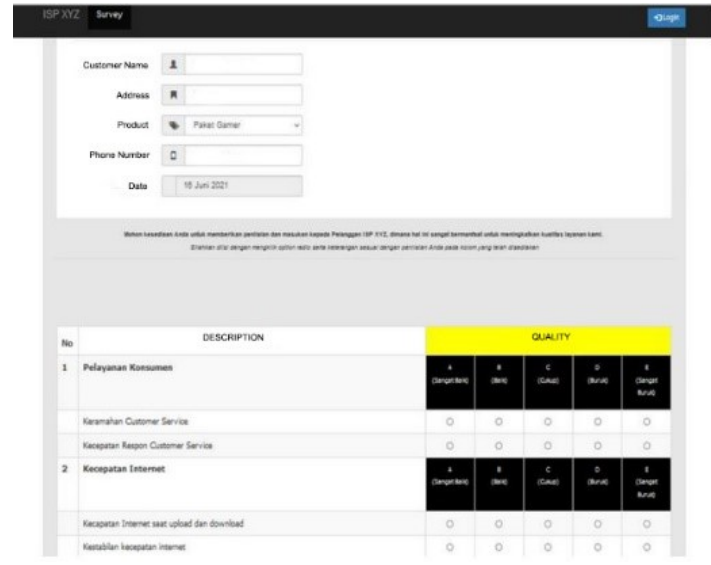

Figure 20. Customer Display

Figure 20 is a display of the Customer page where there are several forms for the Customer's name, address, product, and telephone number that can be filled in and the Customer can choose an answer to answer the questionnaire and add comments/suggestions.

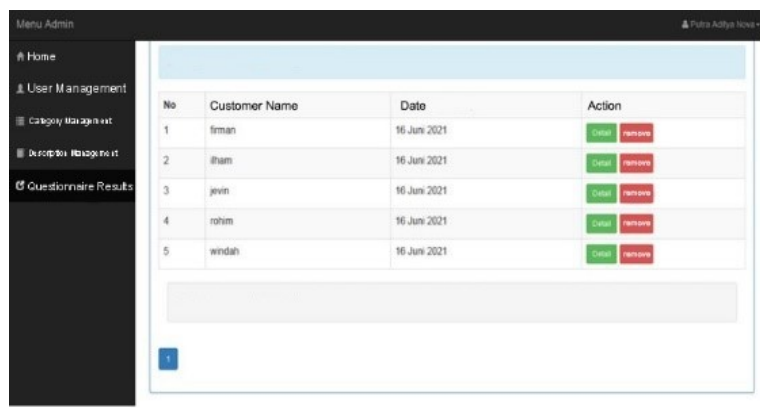

Figure 21. Result Display

Figure 21 shows the results where several respondents have filled out the survey and displayed the date of the survey content, and there is also a detailed feature to view survey results in detail, and a delete feature to delete survey results that are no longer needed.

\section{CONCLUSION}

The conclusion of research in the development of management information systems related to calculating the level of customer satisfaction with the services provided by ISP XYZ is that it is expected to facilitate and speed up the handling of problems that are currently being experienced by customers and by applying the SAW method to the system developed, of course, it can easily find 
out the level of customer satisfaction. Related to the services provided by the company. And based on the evaluation of the application of the SAW method at ISP $\mathrm{XYZ}$, where the SAW method makes it possible to choose an alternative without doing anything complicated calculations, but still applies to the same input data and to the Internet network coverage area as the chosen alternative. Regarding the area of internet network coverage that must be maintained by the ISP company XYZ, because it is a factor that determines customer satisfaction in using the ISP XYZ service facility.

\section{ACKNOWLEDGMENT}

Thank you to the University of 17 Agustus 1945 Surabaya and also the Institute for Research and Community Service of the University of 17 Agustus 1945 Surabaya for providing support and costs related to the university grant research scheme. It is hoped that this research scheme can contribute to the development of science, especially in the field of information systems management in Indonesia.

\section{REFERENCES}

[1] R. Sovia, E. P. W. Mandala, and S. Mardhiah, "Algoritma K-Means dalam Pemilihan Siswa Berprestasi dan Metode SAW untuk Prediksi Penerima Beasiswa Berprestasi," J. Edukasi dan Penelit. Inform., vol. 6, no. 2, p. 181, 2020, doi: 10.26418/jp.v6i2.37759.

[2] Y. M. Kristania, "Implementasi Kombinasi Metode Ahp Dan Saw Dalam Pendukung Keputusan Penentuan Kredit Perumahan Rakyat," Telematika, vol. 11, no. 1, p. 65, 2018, doi: 10.35671/telematika.v11i1.616.

[3] A. Habib, M. A. Jani, D. A. Pratama, and E. Ronando, "Development of archives management information system with RFID and SMS gateway," Int. J. Psychosoc. Rehabil., vol. 24, no.
4, pp. 5227-5243, 2020, doi: 10.37200/IJPR/V24I4/PR201621.

[4] L. Laurentinus and S. Rinaldi, "Implementasi Metode Analytical Hierarchy Process dan Simple Additive Weighting untuk Pemilihan Dosen Terbaik Studi Kasus STMIK Atma Luhur," J. Teknol. Inf. dan Ilmu Komput., vol. 6, no. 6, p. 655, 2019, doi: $10.25126 /$ jtiik.2019661636.

[5] A. Darmawan, "Implementasi Simple Additive Weighting Untuk Monitoring Aktivitas Perkuliahan Dengan Menggunakan Radio Frequency Identification," J. Sist. Inf. Bisnis, vol. 7, no. 1, p. 48, 2017, doi: 10.21456/vol7iss1pp48-58.

[6] B. Berlilana, F. D. Prayoga, and F. S. Utomo, "Implementasi Simple Additive Weighting dan Weighted Product pada Sistem Pendukung Keputusan untuk Rekomendasi Penerima Beras Sejahtera," J. Teknol. Inf. dan Ilmu Komput., vol. 5, no. 4, p. 419, 2018, doi: 10.25126/jtiik.201854768.

[7] A. Habib and A. Kartika W. H., "Development of an Online Sales Information System for SMEs Using Incremental Methods," INTENSIF J. Ilm. Penelit. dan Penerapan Teknol. Sist. Inf., vol. 4, no. 1, pp. 51-62, 2020, doi: 10.29407/intensif.v4i1.13524.

[8] V. C. Hardita, E. Utami, and E. T. Luthfi, "Penerapan Simple Additive Weighting pada Pemilihan Canvasser Terbaik PT.Eratel Prima," J. Teknol. Inf. dan Ilmu Komput., vol. 6, no. 5, p. 567, 2019, doi: 10.25126/jtiik.2019651218.

[9] D. G. H. Divayana, "Pengembangan Model Evaluasi Stake Berbasis ANEKA-Tri Hita Karana dengan Pengkalkulasian SAW dalam Penentuan Aspek-aspek Prioritas Perbaikan Mutu Belajar dan Karakter Siswa," J. Edukasi dan Penelit. Inform., vol. 6, no. 2, p. 143, 2020, doi: 10.26418/jp.v6i2.38557. 
[10] D. Adi Winoto and F. Wahyu Christanto, "Implementasi Google Maps Api Dalam Pengembangan Sistem Informasi Geografis Taman Kota Dan Kampung Tematik Berbasis Android Di Kota Semarang (Studi Kasus: Pejabat Pengelola Informasi Dan Dokumentasi Kota Semarang)," vol. 7, no. 1, pp. 9-16, 2020, doi: 10.25126/jtiik202071051.

[11] H. Budiman, "Peran Teknologi Informasi Dan Komunikasi Dalam Pendidikan," Al-Tadzkiyyah J. Pendidik. Islam, vol. 8, no. 1, p. 31, 2017, doi: 10.24042/atjpi.v8i1.2095.

[12] A. Habib, D. A. Rozi, and G. Kusnanto, "Code of Conduct Information System Using Simple Multi-Attribute Rating Technique (SMART) Method at SMK XYZ," INTENSIF J. Ilm. Penelit. dan Penerapan Teknol. Sist. Inf., vol. 5, no. 1, pp. 86-104, 2021, doi: 10.29407/intensif.v5i1.14728.

[13] K. Rizki and A. Adil, "Implementasi Google Maps API Berbasis Android untuk Lokasi Fasilitas Umum di Kabupaten Sumbawa," J. MATRIK, vol. 17, no. 2, pp. 34-44, 2018, doi: 10.30812/matrik.v17i2.87.

[14] R. L. Pradana, D. Purwanti, and A. Arfriandi, "Sistem Pendukung Keputusan Pemilihan Siswa Berprestasi Berbasis Website dengan Metode Simple Additive Weighting," J. Sist. Inf. Bisnis, vol. 8, no. 1, p. 34, 2018, doi: 10.21456/vol8iss1pp34-41. 